\title{
Are Covered Bonds a Substitute for Mortgage-Backed Securities?
}

Carbo-Valverde, Santiago; Rodriguez Fernandez, Francisco; Rosen, Richard

\section{Journal of Economic Policy Reform}

DOI:

10.1080/17487870.2017.1293537

Published: 01/07/2017

Peer reviewed version

Cyswllt i'r cyhoeddiad / Link to publication

Dyfyniad o'r fersiwn a gyhoeddwyd / Citation for published version (APA):

Carbo-Valverde, S., Rodriguez Fernandez, F., \& Rosen, R. (2017). Are Covered Bonds a

Substitute for Mortgage-Backed Securities? Journal of Economic Policy Reform, 20(3), $238-253$. https://doi.org/10.1080/17487870.2017.1293537

\footnotetext{
Hawliau Cyffredinol / General rights

Copyright and moral rights for the publications made accessible in the public portal are retained by the authors and/or other copyright owners and it is a condition of accessing publications that users recognise and abide by the legal requirements associated with these rights.

- Users may download and print one copy of any publication from the public portal for the purpose of private study or research.

- You may not further distribute the material or use it for any profit-making activity or commercial gain

- You may freely distribute the URL identifying the publication in the public portal ?
}

Take down policy

If you believe that this document breaches copyright please contact us providing details, and we will remove access to the work immediately and investigate your claim. 


\title{
ARE COVERED BONDS A SUBSTITUTE FOR MORTGAGE-BACKED SECURITIES?
}

\author{
Santiago Carbó-Valverde ${ }^{(a)}$ (s.carbo-valverde@bangor.ac.uk) \\ Richard J. Rosen $^{(\mathrm{b})}$ (rrosen@frbchi.org) \\ Francisco Rodríguez-Fernández ${ }^{(\mathrm{c})}$ (franrod@ugr.es)
}

February 2017

\begin{abstract}
Given the problems in the mortgage-backed securities (MBS) market during the financial crisis, some suggest that covered bonds (CB) might be a substitute for MBS. This could lead to a number of policy alternatives in countries where regulation and business have been mainly leaning to one of these types of securities. Examining the use of CB and MBS in the U.S. and Europe, we find that the two often seem to be used for different purposes. Banks are more likely to use $\mathrm{CB}$ when they have liquidity needs while MBS are associated with risk management and agency problems. Introducing MBS to markets where only $\mathrm{CB}$ are common or $\mathrm{CB}$ to markets where only MBS are common could have large effects.
\end{abstract}

JEL: G21, G18

Keywords: covered bonds, MBS, banks, liquidity, risk

The views expressed here are those of the authors and may not represent those of the Federal Reserve Bank of Chicago or the Federal Reserve System. We thank Lamont Black, Ricardo Correa, Scott Stengel, William Treacy, Diego Rodríguez, Gonzalo Camba, Ricardo Gimeno, Philippe Moutot, Maxim Zagonov, Joseph Nichols, and seminar participants at Bocconi University, the Federal Reserve Bank of Chicago, the Federal Reserve Board, the European Central Bank, the University of St. Andrews, the 2012 Asian FMA Conference, and the 2013 MFA Conference for their comments. Financial support from Funcas, MICINN-FEDER ECO2014-59584-P and ECO2015-67656-P, and Junta de Andalucia and P12-SEJ-2463 (Excellence Groups) is gratefully acknowledged by Santiago Carbó-Valverde and Francisco RodriguezFernandez.

\footnotetext{
(a) Bangor University and Funcas

(b) Federal Reserve Bank of Chicago

(c) University of Granada and Funcas.
} 


\section{Motivation and main goal}

The recent financial crisis has a number of causes, but many lay much of the blame on the movement of financing away from traditional bank lending to what is known as the shadow banking system (see, e.g., Adrian and Shin, 2009; Brunnermeier, 2009; Gorton and Metrick, 2011). The shadow banking system includes many things but key among them are the mechanisms by which loans (and loan-like debt instruments) are financed by other than the originating bank. Securitization - the sale of bonds backed by the payments on a group of loans - plays a major role in the shadow banking system. The ability to easily securitize loans in the pre-crisis period abetted the rapid increase in the issuance of the loans that were used as collateral for securitizations. However, the financial crisis exposed a lot of problems with the securitization process, especially for residential mortgages, the largest asset class used to back securitizations. The problems led to a rapid reduction in the issuance of new residential mortgage-backed securities (hereafter MBS). In the aftermath, there has been a search for alternatives to securitization (see Banking Supervision Committee of the European Central Bank, 2011).

One alternative to securitization for residential mortgages is covered bonds (CB), which have been used in some European countries for over a century. In the early stages of the crisis, some critiques on the shortcomings and complexities of the securitization process highlighted the robustness (from a financial stability perspective) of traditional covered bond products (such as German Pfandbriefe). In this paper, we compare MBS to CB and we examine why banks issued each of these types of bonds. This allows us to address the question of whether covered bonds are likely to be a substitute for MBS.

The extent to which CB can be considered as a substitute to MBS has influenced recent proposals to change regulation on securitization in Europe. As part of the capital markets union action plan, the European Commission proposed two legislative measures to promote a safe and liquid market for securitization in 2015 that were still under debate in early 2017. The first one is a regulation that applies to all securitization products and includes due diligence, risk retention and transparency rules together with a clear set of criteria to identify simple, transparent and standardized securitizations. The second one is an amendment to the regulation on capital requirements to make the capital treatment of securitizations for banks and investment firms more risk-sensitive and able to properly reflect the specific features of 
every type of MBS. The latter will likely make it so that MBS have some of the favourable properties of $\mathrm{CB}{ }^{1}$

In this article, we examine banks in Europe and the United States. In some countries Spain and the United Kingdom in particular - both MBS and CB are commonly issued by banks. Analyzing security issuance in these countries allows us to determine the extent to which MBS and CB serve as substitutes. In many other countries, banks tend to issue either MBS, as in the U.S., or CB, as in Germany. We compare the banks in Spain and the U.K. to those in Germany and the U.S. This allows us to estimate the benefits of having active markets for both MBS and CB.

The rest of the paper is as follows. Section 2 gives background on MBS and CB. Then section 3 sets out the empirical model and describes the data we use. The main results are in section 4. Concluding comments are in section 5.

\section{A comparison of $\mathrm{MBS}$ and $\mathrm{CB}$}

\subsection{Definitions and empirical hypotheses}

When examining MBS and $\mathrm{CB}$, which we refer to collectively as secondary mortgage securities or SMS, we focus on several possible reasons why a bank might prefer MBS to covered bonds or vice versa. MBS and CB are both types of bonds that are collateralized by a group of mortgages. They allow banks to fund mortgages using bond markets rather than using deposits or other on-balance sheet liabilities. However, as we delineate below, there are structural and regulatory differences between the two types of securities that may affect how they are used. The null hypothesis in this paper is that the similarity in funding is more important than any differences, that is, that MBS and CB are substitutes:

HO: Banks use CB for the same reasons that they use MBS.

The structure of MBS and $\mathrm{CB}$ means that more risk is transferred from banks to bondholders with MBS than with $\mathrm{CB}$. Using different measures of risk, we find that prior to 2007, securitization increases bank risk. When a bank wants to use MBS to fund mortgages it owns, the bank sells the mortgages to a shell corporation it sets up. ${ }^{2}$ The shell corporation

\footnotetext{
${ }^{1}$ The current proposal for a regulation of the European Parliament on common rules on securitization imposes "a direct risk retention requirement and a reporting obligation on the originator, sponsor or the original lenders. Investors will thus in a simple manner be able to check whether these entities have retained risk." http://eurlex.europa.eu/legal-content/EN/TXT/?uri=CELEX:52015PC0472

${ }^{2}$ We focus on commercial banks that put together securitizations, but it is also done by investment banks and government-sponsored organizations (Fannie Mae and Freddie Mac in the U.S.).
} 
generally is known as a special purpose entity (SPE) or special purpose vehicle. ${ }^{3}$ The SPE issues bonds and uses the revenues from selling the bonds to pay for the mortgages it has purchased. The SPE uses the principal and interest paid on the mortgages to repay the bondholders. The transfer of mortgages to an SPE in a MBS issue means that bondholders (not the issuing bank) bear the risks (default or prepayment) of the mortgages.

In contrast, a bank that issues $\mathrm{CB}$ retains most of the risk of the mortgages backing the $\mathrm{CB}$. To issue a $\mathrm{CB}$, a bank designates a pool of mortgages (known as ring-fencing) then issues bonds collateralized by the pool. ${ }^{4}$ The interest and principal on a covered bond are general obligations of the issuing bank's general funds. If the bondholders are not paid, they have a specific claim on the ring-fenced mortgage collateral pool and a general claim (pari passu with senior creditors) on the assets of the bank. ${ }^{5}$ One other important feature of CB is that if a mortgage in the CB pool defaults or is repaid early, the bank replaces the loan with a new mortgage. ${ }^{6}$ This keeps the size of the pool predictable, reducing default and liquidity risk for bondholders. ${ }^{7}$ Because MBS transfer more risk from banks to bondholders than $\mathrm{CB}$ do, we expect:

\section{H1: Banks are more likely to use MBS than CB for risk management.}

On the flip side, bondholders care about the credit quality of a bank that issues CB because the bank is expected to refresh the mortgage pool and they have a general claim on the bank. Thus:

\section{H2: The risk of the issuing bank is more important for $C B$ than for MBS.}

Another difference between MBS and CB in some countries is their accounting treatment. For $\mathrm{CB}$, the issuing bank includes the ring-fenced pool of mortgages backing the bonds on its balance sheet for accounting purposes. ${ }^{8}$ The issuing bank must hold capital against the bonds under (the standardized approach of) risk-based capital rules. For MBS, accounting and

\footnotetext{
${ }^{3}$ The SPE gives bondholders legal protections if the issuing bank becomes insolvent.

${ }^{4}$ In general, the face value of mortgages in the pool needs to be at least as large as the face value of the CB, although the value of mortgages usually is required to exceed the value of the bonds (overcollateralization). ${ }^{5}$ Commonly, the mortgages backing a covered bond are kept on a bank's balance sheet. However, in the U. K. banks can issue what are known as structured covered bonds. The key difference between structured CB and their more traditional cousins is that the issuer of structured CB is a limited liability partnership (analogous to an $\mathrm{SPE}$ ). The partnership purchases the mortgages from the issuer and guarantees the bonds. This serves as a different way of ring-fencing the mortgages. But even in a structured CB issue, bond holders have a residual claim on the bank that is the general partner of the partnership (essentially, the issuer of the bonds).

${ }^{6}$ Investors still care about the credit quality of the cover assets (Prokopczuk et al., 2013).

${ }^{7}$ Since the mortgages are naturally amortizing, the size of the pool can fall over time.

${ }^{8}$ The key is that the bank offers a general guarantee of the covered bonds. This obligates the consolidated treatment even for structured covered bonds.
} 
capital treatment can depend on the country where the issuing bank resides. There is a true sale of the mortgages that go into a SPE for an MBS and the issuing bank offers no guarantee to bondholders. The differences in accounting and regulatory capital rules indicate that:

\section{H3: Banks are more likely to use MBS than CB for capital management.}

However, some countries such as Spain require any assets in an SPE to be consolidated on bank balance sheets. Thus, Spanish banks that securitized mortgages are required to hold capital against the loans in the SPE. ${ }^{9}$ This makes it less likely that $H O$ will be rejected in favor of $H 3$.

\subsection{Data}

We get balance sheet and income statement data from Bankscope and data on SMS issuance from Dealogic. Since there are fixed costs to issue SMS, we include only banks with at least one billion dollars of total assets at the beginning of our sample period. To remove potential outliers, we trim our data at the $1^{\text {st }}$ and $99^{\text {th }}$ percentile of all variables used in the empirical analysis. ${ }^{10}$

The primary sample includes 377 banks including 42 that issue $\mathrm{CB}$ at least once and 38 that issue MBS at least once. Table I presents summary statistics for the sample presented three ways: for the full sample, for banks that only issue MBS, and for banks that only issue CB. ${ }^{11}$ For MBS and CB issuers, the data are for the year before the year in which the SMS was issued (a bank is in the data once for each year that it issues CB or MBS). There are 1,850 bank-year observations in our sample, of which $130(7.03 \%)$ involve a MBS issue and $141(7.62 \%)$ have a CB issue.

During 2003-2007, mortgage-backed securitization was common in some countries, but rare in others. Among the countries we focus on, the U.S., Spain, and the U.K. had active securitization markets while there was essentially no MBS issuance in Germany (see Table

\footnotetext{
${ }^{9}$ During the period we study, this was not true in the U.S. But the U.S. Financial Accounting Standards Board approved Financial Accounting Standards (FAS) 166 and 167 which took effect in late 2009. FAS 166 and FAS 167 state that some types of securitizations, but not necessarily MBS, have to be consolidated on a firm's balance sheet. The FDIC said that this would apply to regulatory capital but delayed the implementation of the requirement.

${ }^{10}$ All the empirical tests in this paper were re-run with winsorized data as opposed to the trimming of the $1^{\text {st }}$ and $99^{\text {th }}$ percentiles. The results are qualitatively similar.

${ }^{11}$ We use bank-level data rather than data for the parent holding company.
} 
II). ${ }^{12}$ In part, the lack of securitization in Germany is due to a combination of regulatory and historical factors (Deutsche Bundesbank, 1997).

Similarly, during our sample period, covered bonds markets were active in Germany, Spain, and the U.K. but not in the U.S. ${ }^{13}$ In part, this is due to regulation. The deposit insurer in the U.S. (the FDIC) has not clarified how bondholders will be treated when an issuing bank becomes insolvent, including whether bondholders have priority over the FDIC. ${ }^{14}$ This means that the mortgages that are intended as collateral for CB may be claimed by the FDIC when a bank fails, increasing the risk for covered bondholders. One question we address is whether MBS may have served as a substitute for CB issuance in the U.S. ${ }^{15}$

\section{Empirical model}

\subsection{Empirical methodology: a two-stage approach}

Our goals are to determine the factors that lead a bank to issue SMS and to estimate the effect of SMS issue on characteristics of the issuing bank. When estimating our empirical model, we account for the relationship between these two factors using a two-stage approach. Stage one refers to the reasons behind the issuance of a particular type of SMS (and it also controls for the possibility of no issuance) while stage two look at the effects of the first-stage choice on bank liquidity, risk and other performance indicators. This introduces potential biases in the errors.

To model the two-stage decision of banks about SMS issue, we use the discretecontinuous model (Dubin and McFadden, 1984, DM) that is a generalization of Heckman's (1979) two-step selection model. It takes into account the first-stage choice between not issuing, issuing MBS or issuing covered bonds. The DM two-step estimation uses a multinomial logit model in the first stage and then estimates a conditional model of the

\footnotetext{
${ }^{12}$ Dealscan reports one extremely small securitization in our sample by a German bank. We drop this in our analysis below.

${ }^{13}$ Non-U.S. banks have issued U.S. dollar-denominated covered bonds. These were issued after our sample ended, but had they been issued during the sample period we would have classified the securities by the home country of the issuing bank.

${ }^{14}$ Two U.S. banks issued CB in 2006 using the British structured covered bond framework (see Table II). We drop these from our analysis.

${ }^{15}$ U.S. banks also have the option of borrowing from a Federal Home Loan Bank (FHLB). The FHLBs are government-sponsored entities that have as one of their goals helping housing finance (see Flannery and Frame, 2006, for more details on the FHLBs). Member banks are allowed to borrow from FHLBs using mortgages as collateral for the loans. FHLB loans can be used for any purposes.
} 
effects of each choice of bank $i$ in country $c$ and time $t$, on bank characteristics using panel data with fixed effects and the selection correction. In our estimate, we assume underlying selection process follows a normal distribution (Bourguignon et al., 2007). ${ }^{16}$ The logit equation for the first-stage choice equation is:

$$
\begin{aligned}
\ln \left(p_{i, j, c, t} /\left(n p_{i, c, t}\right)\right) & = \\
\eta & +\beta\left(\text { bank characteristics }_{i, c, t-1}\right)+\rho\left(\text { deal-specific variables }_{c, t}\right)+\varepsilon_{i, t}
\end{aligned}
$$

where

$$
\begin{aligned}
& p_{i, j, c, t}=\operatorname{Pr}\left(S M S \text { issuance }_{i, c, t} \text { of type } \mathrm{j}=1\right), \mathrm{j} \text { is either CB or MBS, } \\
& n p_{i, c, t}=\operatorname{Pr}\left(\text { SMS }_{\text {issuance }_{i, c, t}}=0 \text { for both CB and MBS }\right)
\end{aligned}
$$

and the error terms in the choice equations are independent with identical Gumbel distributions. The second-stage regression incorporates the selection correction from the firststage, and it is written as follows:

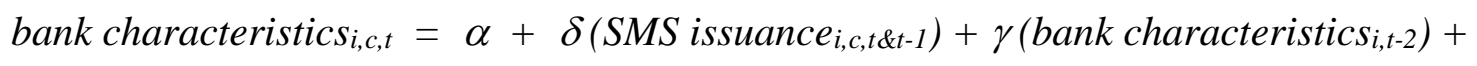

$$
\lambda_{i, t}+\zeta_{i}+v_{c}+\mu_{i, t}
$$

where $\lambda_{i, t}$ is the selection correction from the first stage, $\zeta_{\mathrm{i}}$ is a bank dummy (a fixed effect) and $v_{c}$ is a country dummy. ${ }^{17}$ The bank characteristics we examine include return on assets (ROA), the loan-to-deposit ratio, loan growth, the capital ratio, and the ratio of loan provisions to total loans. We discuss the identification of the model and what each of these variables represents below. We estimate (2) separately for each bank characteristic but we include lagged values of the rest of the dependent variable in each regression. We control for previous SMS issuance by including dummies for whether a bank has issued a particular kind of SMS in the prior two years (not shown in equation (2) for simplicity).

To investigate the decision to issue a SMS, we initially focus on Spain and the U.K. Banks in these countries are able to choose among CB, MBS, and no SMS issue. After running the model for the U.K. and Spain, we follow this up by examining CB issuance in Germany and MBS issuance in the U.S. First, we estimate (1) and (2) where the decision of banks is whether to issue a specific security (CB in Germany and MBS in the U.S.) versus

\footnotetext{
${ }^{16}$ We use the Stata selmlog command developed by Bourguignon et al. (2007).

${ }^{17}$ In an alternative specification we also include a dummy in equations (1) and (2) to reflect whether the bank has a foreign parent (which will potentially permit such bank to issue a SMS in other geographic locations). The introduction of the dummy does not change the results of our baseline model.
} 
non-issuing. ${ }^{18}$ Then, we use the estimates of (2) for Spain and the U.K. to ask how SMS issuance would change if Germany had an active MBS market and the U.S. had an active CB market. We do this by assuming that banks in Germany and the U.S. choose similarly to those in Spain and the U.K.

\subsection{The selection of bank characteristics}

The bank characteristics included in the analysis are limited by data availability. The Bankscope dataset we use do not have widespread coverage of some balance sheet and income variables for many of the banks in the sample countries. The variables we use are intended to cover basic measures of profit, liquidity, and risk while also allowing us to include as large a sample of banks as possible. Profit is measured using return on assets (ROA), that is, income during the year divided by total assets at the end of the year (the results are robust to using the return on equity).

The first measure of risk we use is the loan-to-deposits ratio. Since loans are generally illiquid and deposits are generally liquid, higher values of this ratio suggest a less liquid, and therefore riskier, bank. But, this ratio has a problem when we want to look at the effect of $\mathrm{CB}$ issue on liquidity. The mortgages that back a CB remain on a bank's balance sheet, thus inflating the bank's reported loans. From a liquidity perspective, these mortgages are different from other loans (including other mortgages) at a bank because they are matched to liabilities with a similar maturity profile. ${ }^{19}$ For this reason, we create a CB-free loans-todeposits ratio by subtracting the mortgages backing $\mathrm{CB}$ from total loans. ${ }^{20}$ We use this adjusted loans-to-deposits ratio in the analysis below.

The capital-to-assets ratio (henceforth, the capital ratio) is also used to measure risk. Clearly, the smaller the capital buffer, the more likely insolvency is. One issue with the capital ratio is that regulators set minimum capital ratios for banks. We include a separate variable for banks with low capital on the grounds that low-capital banks are likely to face more regulatory scrutiny. Since regulatory capital minimums are based on risk-based capital measures and we do not have these ratios, we define a low-capital bank as one with a capital

\footnotetext{
${ }^{18}$ Our results are robust to including Germany, Spain, the U.S., the U.K. plus other European countries in a single regression.

${ }^{19}$ There may be some minor liquidity issues because the mortgages in the CB pool have the risk of unexpected default and prepayment.

${ }^{20}$ Formally, the numerator of the adjusted loans-to-deposits ratio in year $t$ is the total loans in year $t$ minus the sum of all covered bonds issued in the years from 2003 to year $t$, inclusive.
} 
ratio in the lowest $25 \%$ in a given year. The low-capital variable is the interaction between the capital ratio and a zero-one dummy for whether a bank has low capital.

The loan-to-deposits ratio and the capital ratio do not separate banks by the riskiness of the assets they invest in, beyond the notion that loans are often riskier than other bank assets. To further refine our estimate of bank risk, we use the ratio of loan loss provisions to total loans. Loan loss provisions are the capital that a bank sets aside to cover changes in future expected losses on loans the bank has made. It is, thus, an ex ante measure of the risk of a loan portfolio. ${ }^{21}$ We also include loan growth in our analysis. Loan growth is the percentage change in loans from one year-end to the next year-end. More liquid banks should be able to make more loans, thereby growing faster.

Table III summarizes our hypotheses about how the regression results are related to the reasons for issuing SMS.

\subsection{First-stage specific variables}

For identification reasons, we include four specific variables in our security choice firststage equation. The first is a score based on the credit rating of a deal. We use the issuer's rating at issuance given by Moody's as reported to Dealogic. We transform these ratings into conventional numerical scores by assigning the highest rates (AAA) a value of one and then adding 1 for each notch a rating is worse than the highest (so a $\mathrm{C}$ rating from Moody's has a value of 21). This is similar to many other papers (for example, Avramov et al., 2009). The Issuer's rating score at origin is then expressed as 100 minus the rating values so that a higher score expresses higher credit quality. We also include a dummy to control for whether a bank has a foreign parent. Additionally, two variables capture market trends: the growth of MBS issuance in the national market in the previous year and the growth of CB issuance in the national market in the previous year. These variables affect the issuance decision but should have no effect on how issuance affects bank characteristics. This allows us to use the Dubin-McFadden procedure to jointly identify factors that influences the SMS issuance and the impact of the issuance on the issuers.

\footnotetext{
${ }^{21}$ As discussed later, the results are robust to using the ratio of chargeoffs to total loans, which is an ex post measure of bank risk.
} 


\section{Regression results}

\subsection{The impact of bank characteristics on the decision to issue SMS}

The first stage of the empirical model is a logit selection equation that examines whether a bank issues a SMS in a particular year. When reporting results, we choose the case where banks do not issue SMS as the baseline. This means that the two other alternatives, issuing $\mathrm{CB}$ and issuing MBS, are compared to not issuing SMS.

The first column of Table IV reports the coefficients for the comparison of issuing CB to not issuing SMS for banks in Spain and the U.K. The coefficient on ROA of -3.028 is significantly different from zero. This means that banks with lower ROA in year $\mathrm{t}-1$ are more likely to issue $\mathrm{CB}$ in year $\mathrm{t}$. To get a feel for the economic significance of this effect, we calculate the impact of marginally increasing ROA on the probability of issuing a $\mathrm{CB}$ for a bank with the mean values for all the other variables. This value, referred to as the marginal effect in the tables, shows that the probability of issuing a $\mathrm{CB}$ decreases by 5.22 percentage points per percentage point increase in ROA. ${ }^{22}$

The results for the CB columns in Table IV also show that banks with larger (adjusted) loan-to-deposits ratios, larger capital ratios, lower provisions, and larger total assets are more likely to issue CB when compared with not issuing SMS. The largest economic impact in this group of variables comes from the total assets variable, consistent with there being a substantial fixed cost to issue a covered bond, with larger banks able to spread the cost over a bigger pool of loans. But the impact of the loan-to-deposits ratio and the capital ratio are also significant. Finally, there is no significant relationship between CB issuance and any of the low capital ratio dummy, loan growth, or the home price index.

A comparison of issuing MBS to not issuing SMS is given in the MBS columns of Table IV. Banks with larger loan-to-deposits ratios, larger provisions, and larger total assets are more likely to issue MBS than not issue SMS. In addition, MBS are more common when home prices are higher.

We can also compare CB to MBS. The final column of Table IV reports the p-values for tests of whether the coefficients in the first column of the table are equal to those in the second column. Overall, we see significant differences in the impact bank characteristics have on the decisions to issue $\mathrm{CB}$ relative to MBS. For example, the p-value for ROA is 0.001, meaning that the coefficient on ROA in the comparison of issuing $\mathrm{CB}$ to not issuing

${ }^{22}$ There is a need to be careful when extrapolating from the marginal effect since it only holds exactly for a tiny change in ROA 
SMS is significantly smaller than the coefficient on ROA in the comparison of issuing MBS to not issuing SMS. However, these differences do not fit a simple pattern such as bank characteristics being more important for one type of SMS.

Overall, banks with low liquidity are more likely to issue SMS, as the coefficients on ROA and the loan-to-deposits ratio have signs consistent with this (although the coefficient on ROA in the MBS regression is not significant). Banks that issue CB are, by most measures, safer than average. They have larger capital buffers and lower provisions although they also have a larger loans-to-deposit ratio. The banks that issue MBS, on the other hand, appear riskier than average. They have loans-to-deposits ratios and loan provisions that are significantly above those of banks that do not issue SMS. Additionally, as noted above, it is clear that asset size is an important predictor of which banks issue SMS, something that we explore in the robustness checks that follow.

Several robustness tests are discussed briefly here. First, we can replace the adjusted loan-to-deposit ratio with the balance sheet loan-to-deposits ratio (which includes the CB loan pool) without changing the qualitative results. Second, one issue with the baseline specification is that our measure of loan risk, provisions, is subject to strategic behavior by banks. There is evidence that banks have used provisions to smooth income, for example (Saurina, 2009; Sacasa, 2011). An alternative measure of loan risk is the ratio of loan chargeoffs to total loans. This is an ex post measure of losses, reflecting losses on loans made in the past and therefore might be less relevant for SMS issuance decisions today. We can replace provisions with chargeoffs without changing the qualitative results. Third, we control for country effects using dummies, but it is possible that the cross-country differences are more subtle. To test this, we subtract from each of the bank characteristics the average value of that characteristic for banks in our sample from the same country. Using the netted variables as our controls not surprisingly affects the magnitudes of the coefficients in the regressions. However, the same set of variables is statistically significant as in the baseline results. Fourth, consistent with there being a large fixed cost to issue SMS, we find that large banks are more likely to issue these bonds than are small firms. Our results also are robust to dropping all small banks from the sample. Finally, the overall predictions remain qualitatively similar to those in the baseline model when we include interaction terms between bank size and the other variables.

\subsection{The impact of SMS issue on bank characteristics}

Following the empirical model, the effect of SMS issuance choice on bank characteristics are estimated in the second-stage regression as suggested by equation (2). Selected 
coefficients for banks in Spain and the U.K. are reported in Table V. We pool the banks in these countries (but include country dummies). Each column in the table represents the regression for a different bank characteristic. The coefficients on the SMS dummies are given in the table while the other control variables given in (2) are included in the regressions but not reported.

There is evidence that issuing $\mathrm{CB}$ is associated with improved profitability. The coefficients on both $\mathrm{CB}$ variables in the regressions reported in the first column of Table $\mathrm{V}$ are positive and significantly different from zero. The coefficient on the $\mathrm{CB}$ dummy in the first row is 0.085 , meaning that a bank in Spain or the U.K. that has issued CB in the past two years has a ROA that is 0.85 larger than that of a non-issuing bank in those countries. This is $9 \%$ of the mean and $35.5 \%$ of the standard deviation of ROA for banks in the sample.

The results are also consistent with banks issuing $\mathrm{CB}$ to meet existing liquidity needs. The increase in ROA after a $\mathrm{CB}$ issue suggests an increase in liquidity. Another measure of liquidity we use is the adjusted loan-to-deposits ratio. As shown in the first row of the second column of Table VI, the coefficient on the CB dummy is -0.041 , which is significantly less than zero. Since the standard deviation for the adjusted loan-to-deposit ratio is 0.17 , issuing $\mathrm{CB}$ leads to a decrease of 0.24 standard deviations in the ratio. This is consistent with issuing $\mathrm{CB}$ to meet an existing liquidity need but not with the ability to issue $\mathrm{CB}$ allowing a bank to reduce the liquidity of its balance sheet. For reference, if we run the same regression with the unadjusted loan-to-deposit ratio, the coefficient on the $\mathrm{CB}$ dummy is 0.031 , which is significantly greater than zero (regression not shown). Thus, while issuing $\mathrm{CB}$ increases the loan-to-deposit ratio, it does so primarily because the mortgages backing $\mathrm{CB}$ stay on the issuing bank's balance sheet.

The loan growth regression provides a further check on liquidity changes. As shown in Table IV, an increase in loan growth after a SMS issue suggests that the issuance opened up space for the bank to grow. However, we do not find that banks significantly increase loan growth after $\mathrm{CB}$ issuance, although the coefficient on the CB dummy is of the correct sign for that (column 3 in Table V).

Issuing CB is associated with lower risk. Following issuance, banks have lower adjusted loan-to-deposit ratios (column 2 in Table V) and larger capital ratios (column 4 in Table V). However, the impact on capital ratios is relatively small. Issuing a CB increases a Spanish or U.K. bank's capital ratio by 0.070 , or $3.5 \%$ of the standard deviation of the capital ratio.

Low-capital banks also might be using CB to stay above regulatory capital minimums. The capital ratio of a low-capital bank increases following a CB issue (column 5 in Table V). But this may be no more than the standard risk reduction from increased capital, as the 
coefficient on the $\mathrm{CB}$ dummy in the low capital ratio regression (column 5) is significantly smaller than the coefficient on the $\mathrm{CB}$ dummy in the full sample capital ratio regression (column 4).

The effect of securitizing mortgages is different than the effect of issuing a covered bond. The impact of MBS issue on profit is insignificant and economically small in magnitude. There is also evidence consistent with the ability to issue MBS allowing banks to keep less liquid balance sheets as the coefficients on the MBS dummy in the lower adjusted loan-todeposit ratio regression (column 2 in Table V) are positive and significant. This result is consistent with Loutskina (2011) although, unlike her, we do not find that banks with access to MBS markets grow faster (column 3 in Table V).

There is evidence that issuing MBS might reduce risk. Banks that issue MBS have lower provisions post-issue (column 6 in Table V) and issuing MBS also leads to slower loan growth (column 3 in Table V). ${ }^{23}$

All the results in Table VI remain significant when the explanatory variables are shown as one-year lag instead of two-year lag, although the coefficients are smaller in magnitude (not shown for simplicity).

There are some banks that issue more often than others. In unreported results, we show that the economic impact of issuing on bank characteristics is generally smaller for first-time issuers. It is also larger for active issuers than less active issuers, all else equal.

\subsection{SMS issuance in Germany and the U.S.: actual and predicted}

The next step in our analysis is to examine SMS issuance in the countries where one of the markets is inactive. For the reasons discussed earlier, there are barriers to issuing MBS in Germany and $\mathrm{CB}$ in the U.S. To look at the impact of these barriers, we examine the issuance decision for the SMS market that is active in each country. This allows us to see whether banks are issuing SMS for similar reasons in the unconstrained countries as in the constrained countries. Our analysis does not capture the full cost of the missing SMS markets because we take the portfolio of a bank as given. The difficulties of issuing MBS in

\footnotetext{
${ }^{23}$ Using different measures of risk, Le et al. (2016) find that securitization increased risk at U.S. banks prior to 2007 but not after 2009 .
} 
Germany and CB in the U.S. may affect the decision to originate mortgages, something we cannot pick up. ${ }^{24}$

The results for CB issuance in Germany and MBS issuance in the U.S are not shown for simplicity but they are available upon request. The coefficients are similar in sign and significance to the baseline results shown in Tables IV and V. This suggests that common factors drive the SMS issuance across countries.

Making use of the estimated coefficients of the subsample of Spanish and U.K. banks in Table V, it is possible to simulate the extent to which CB issuance in Germany and MBS issuance in the U.S. might change if the other type of security (MBS in Germany and CB in the U.S.) was easy to issue. We do this in two steps. First, we explore whether banks that issued CB in Germany would have issued MBS if the barriers to MBS issue were not present. We do the same for banks switching from MBS to CB in the U.S. The second step is to estimate which banks that did not issue a SMS would have issued one if the barriers to issuing MBS in Germany and CB in the U.S. were not there.

We rely on the baseline regressions for Spain and the U.K. to estimate the number of banks that would switch the type of SMS they issue if barriers in Germany and the U.S. were lower. The results are shown in Table VI. For each German bank that issues a covered bond in a year, we ask whether they prefer MBS to CB using the coefficients reported in Table V. To do this, we calculate the predicted probabilities of issuing MBS and of issuing CB. If the probability of issuing MBS is larger than the probability of issuing $\mathrm{CB}$ we assume that the bank switches from CB to MBS. Our estimates imply that $20.5 \%$ of German banks that issue $\mathrm{CB}$ in a year would be more likely to issue MBS that year if they were in a Spanish-U.K. environment. A similar exercise for U.S. banks suggests that for $25.2 \%$ of MBS issuers, CB would be preferred if there were no barriers to CB issuance.

To estimate the number of SMS non-issuers who might issue if barriers were lower, we find, for each bank in Germany that does not issue $\mathrm{CB}$, the probability that bank would issue MBS. We do this using the coefficients in the MBS columns in Table V. So, for example, a German bank with the right-hand side variables equal to the sample means would have a predicted probability of issuing MBS of $11.2 \%$. We then sum these probabilities to get the expected number of non-CB issuing banks that would issue MBS in Germany. As reported in the second row of Table VI, we estimate that there would be 35 MBS issues from these

\footnotetext{
${ }^{24}$ For example, German financial regulation allows German insurance companies and pension funds to invest in CB but not in MBS. Implicitly, we are assuming that if German banks were allowed to issue MBS then German insurance companies would be allowed to invest in MBS. To the extent that there are restrictions such as the one on MBS investment by insurance companies that are not lifted, our results will overstate the shift to MBS.
} 
banks. Since German banks issued $96 \mathrm{CB}$ during our sample, adding $35 \mathrm{MBS}$ would significantly increase total SMS issuance.

We conduct a similar exercise to find the proportion on non-MBS issuing U.S. banks that would issue $\mathrm{CB}$ if the conditions for $\mathrm{CB}$ issuance were similar to those in Spain and the U.K. We estimate that there would be $78 \mathrm{CB}$ issues during our sample period, large compared to the 91 MBS issues we actually observe. ${ }^{25}$

For both Germany and the U.S. we find that the barriers to issuing SMS are important. If SMS markets in Germany and the U.S. were like those in Spain and the U.K., between 20\% and $25 \%$ of banks might switch from $\mathrm{CB}$ to MBS or vice versa. In addition, a number of banks might start issuing SMS. Note that we do not estimate the welfare loss, if any, from the barriers. It could be that the gains from lowering the barriers are low.

\section{Concluding comments}

Covered bonds and mortgage-backed securities are similar in the main economic function they perform: allowing banks to finance mortgages using duration-matched bonds. This has led some to suggest that, given the troubles in MBS markets following the recent financial crisis, that $\mathrm{CB}$ could be a good substitute for MBS. We examine whether banks, prior to the crisis, were using $\mathrm{CB}$ and MBS for the same reasons.

We find evidence that $\mathrm{CB}$ and MBS are used by banks for different reasons (see Table VII for a summary). Banks were more likely to use CB when they were liquidity constrained, and the use of $\mathrm{CB}$ improved liquidity. After using MBS, however, banks held less liquidity. There is also some indication that banks used MBS when they were attempting to reduce risk. The same is not true for $\mathrm{CB}$.

Differences in the usage of $\mathrm{CB}$ and MBS suggest that having both types of secondary mortgage security available would change bank behavior. We offer support for this by comparing countries where $\mathrm{CB}$ and MBS are both commonly used by banks with countries where only one of the two types of securities is common. We estimate that if MBS markets in Germany, where banks did not issue MBS in our sample period, were like those in Spain and the U.K., where both CB and MBS were issued, many banks might switch from issuing CB to issuing MBS. Similarly, if regulatory issues surrounding CB issuance in the U.S. were resolved so that U.S. CB markets were like those in Spain and the U.K., we estimate that a

${ }^{25}$ Note that this estimate should be viewed with caution since we do not control for borrowings from the FHLBs. 
significant share of the banks that issue MBS would instead issue CB. In both Germany and the U.S., opening up the dormant SMS channel would also lead banks that would not otherwise issue SMS to issue them. This shows the benefits to banks from having active SMS markets. However, it also shows that while CB may be a workable alternative to MBS, they are not a perfect substitute.

Although banks might benefit from having access to both $\mathrm{CB}$ and MBS, that does not mean that opening both channels is necessarily socially beneficial. The policy question of whether to allow CB, MBS, or both is complicated. Banks would benefit but there are potentially offsetting costs. As noted, many blame the recent financial crisis in part on MBS. This cost is not captured in our analysis. Problems with CB during the crisis were much less severe than for MBS. This suggests that countries with MBS but not $\mathrm{CB}$ might want to increase incentives for (or reduce impediments to) $\mathrm{CB}$ markets even if the two are not perfect substitutes. However, there are some potential issues with $\mathrm{CB}$ as they can be used as a form of regulatory arbitrage when there is deposit insurance. The holders of covered bonds - by having a protected and refreshed collateral pool - effectively are senior to the deposit insurer in a bank insolvency. Depending on the details of the bank deposit insurance system, this can increase the cost to taxpayers from bank insolvencies (and change the incentives for the bank to take on risk). Thus, while our paper should be viewed as showing one set of benefits from allowing both CB and MBS markets to exist, there are other costs that need to be considered as well. This is a good topic for future research. 


\section{References}

Adrian, Tobias, and Hyun Song Shin (2009) "Money, Liquidity, and Monetary Policy." American Economic Review Papers and Proceedings 99(2), 600-605.

Avramov, D., Chordia, T. Jostova, G.and A. Philipov (2009) "Dispersion in analysts' earnings forecasts and credit rating" Journal of Financial Economics 91, 83-101

Bourguignon F., Fournier, M., Gurgand (2007) "Selection Bias Corrections Based on the Multinomial Logit Model: Monte-Carlo Comparisons", Journal of Economic Surveys, 21(1), 174-205.

Brunnermeier, Markus K. (2009) "Deciphering the Liquidity and Credit Crunch 2007-08", Journal of Economic Perspectives, 23(1), 77-100.

Deutsche Bundesbank (1997) "Asset-backed securities in Germany: the sale and securitisation of loans by German credit institutions," Deutsche Bundesbank Monthly Report, July.

Dubin, J. A. and McFadden, D. L. (1984) "An econometric analysis of residual electric appliance holdings and consumption", Econometrica 52, 345-362.

European Central Bank (2011) "Recent Developments in Securitization”, report by the Banking Supervision Committee. February.

Flannery, Mark J. and W. Scott Frame (2006) "The Federal Home Loan Bank System: The "Other" Housing GSE," Economic Review, Federal Reserve Bank of Atlanta, Third Quarter 2006, 33-54.

Gorton, Gary and Andrew Metrick (2011) "Securitized Banking and the Run on Repo," Journal of Financial Economics.

Heckman, J. (1979) "Sample Selection Bias as Specification Error", Econometrica 47, 153-161.

Loutskina, Eelena (2011), "The role of securitization in bank liquidity and funding management". Journal of Financial Economics, 100, 663-684.

Prokopczuk, Marcel, Siewert, Jan B. and Volker Vonhoff (2013) "Credit risk in covered bonds", Journal of Empirical Finance, 21 (2013) 102-120

Sacasa, Noel (2011) "Implementing Rules-Based Stabilizers for Banks: A Simplified Simulation for the United States 1992-2007", IMF Working Paper (Washington: International Monetary Fund).

Saurina, Jesús (2009) "Loan-loss provisions in Spain. a working macroprudential tool", Financial Stability Review- Bank of Spain 17, 9-26. 


\section{Table I. Descriptive statistics}

Based on a sample of 377 banks in Germany, Spain, the U.S., and the U.K. from 2003-2007. To be in the sample, a bank must have at least $\$ 1$ billion in assets. Not all banks issued MBS or CB while some banks issued MBS and/or CB multiple times.

\begin{tabular}{|l|l|l|l|l|l|l|l|l|l|}
\hline & \multicolumn{3}{|l|}{ ALL SAMPLE } & \multicolumn{3}{l|}{ MBS ISSUERS } & \multicolumn{3}{l|}{ CB ISSUERS } \\
\hline & Mean & Median & $\begin{array}{l}\text { Std. } \\
\text { Dev. }\end{array}$ & Mean & Median & $\begin{array}{l}\text { Std. } \\
\text { Dev. }\end{array}$ & Mean & Median & Std. Dev. \\
\hline ROA (\%) & 0.73 & 0.70 & 0.22 & 0.66 & 0.61 & 0.17 & 0.83 & 0.75 & 0.24 \\
\hline $\begin{array}{l}\text { Loans-to-deposits ratio } \\
\text { \%) }\end{array}$ & 0.81 & 0.74 & 0.12 & 0.87 & 0.80 & 0.17 & 0.78 & 0.76 & 0.11 \\
\hline $\begin{array}{l}\text { Adjusted loans-to- } \\
\text { deposits ratio (\%) }\end{array}$ & 0.72 & 0.70 & 0.16 & 0.81 & 0.76 & 0.19 & 0.68 & 0.65 & 0.16 \\
\hline Capital ratio (\%) & 5.97 & 5.50 & 2.13 & 5.57 & 5.50 & 2.27 & 6.38 & 6.27 & 2.13 \\
\hline $\begin{array}{l}\text { \% of banks with a low } \\
\text { capital ratio (Low CR) }\end{array}$ & 24.96 & - & - & 34.04 & - & - & 18.61 & - & \\
\hline $\begin{array}{l}\text { Capital ratio of banks } \\
\text { in the Low CR group } \\
\text { (\%) }\end{array}$ & 4.12 & 3.85 & 2.02 & 3.89 & 3.82 & 2.19 & 4.23 & 4.04 & 2.12 \\
\hline $\begin{array}{l}\text { Provisions-to-loans } \\
\text { ratio (\%) }\end{array}$ & 8.62 & 8.01 & 3.23 & 7.18 & 7.10 & 3.30 & 9.13 & 8.79 & 3.26 \\
\hline $\begin{array}{l}\text { Net charge-offs ratio } \\
\text { (\%) }\end{array}$ & 0.44 & 0.53 & 0.26 & 0.41 & 0.43 & 0.17 & 0.31 & 0.33 & 0.17 \\
\hline Loan growth (\%) & 8.11 & 9.35 & 1.85 & 12.10 & 12.23 & 1.79 & 9.13 & 9.42 & 1.91 \\
\hline Total assets (\$ bil.) & 38.48 & 40.03 & 6.17 & 39.24 & 40.13 & 6.72 & 36.12 & 37.59 & 5.43 \\
\hline Total assets (log) & 10.55 & 10.43 & 2.12 & 10.72 & 10.50 & 2.13 & 10.71 & 10.29 & 2.34 \\
\hline Rating at issuance & 92.4 & 91.7 & 10.6 & 89.7 & 89.9 & 11.7 & 93.4 & 93.1 & 10.8 \\
\hline Observations & 1850 & 377 & & 130 & & & 141 & & \\
\hline Banks & & & & & & & & & \\
\hline
\end{tabular}

Note: Information on CB issuers and MBS issuers is shown only for the year prior to when a security was issued. 


\section{Table II. SMS issue by country}

Based on a sample of 377 banks in Germany, Spain, the U.S., and the U.K. from 2003-2007. To be in the sample, a bank must have at least $\$ 1$ billion in assets. Not all banks issued MBS or CB while some banks issued MBS and/or CB multiple times.

\begin{tabular}{|c|c|c|c|c|c|c|c|}
\hline & \multirow{2}{*}{$\begin{array}{l}\text { All banks } \\
\text { Obs. }\end{array}$} & \multicolumn{3}{|c|}{ MBS } & \multicolumn{3}{|l|}{$\mathrm{CB}$} \\
\hline & & Obs. & \begin{tabular}{|l|} 
Average \\
issue size \\
$(\$$ mil. $)$
\end{tabular} & \begin{tabular}{|l|} 
Average \\
issuer size \\
(\$bil)
\end{tabular} & Obs. & \begin{tabular}{|l} 
Average \\
issue size \\
(\$ mil.)
\end{tabular} & $\begin{array}{l}\text { Average } \\
\text { issuer size } \\
\text { (\$bil) }\end{array}$ \\
\hline Full sample & 1850 & 172 & 1,072 & 76.6 & 202 & 569 & 41.3 \\
\hline Germany & 402 & - & - & - & 96 & 627 & 46.7 \\
\hline Spain & 284 & 43 & 286 & 33.8 & 58 & 445 & 31.8 \\
\hline U.K. & 212 & 38 & 375 & 41.1 & 48 & 602 & 42.1 \\
\hline U.S. & 952 & 91 & 1,734 & 111.7 & - & - & - \\
\hline
\end{tabular}


Table III. Predicted signs on the regression coefficients

\begin{tabular}{|c|c|c|c|}
\hline & $\begin{array}{l}\text { Possible reason for issuing SMS: } \\
\text { Before issue }\end{array}$ & $\begin{array}{l}\text { Direct effect of issuing SMS: } \\
\text { After issue }\end{array}$ & $\begin{array}{l}\text { Indirect effect of issuing SMS: } \\
\text { After issue }\end{array}$ \\
\hline \multicolumn{4}{|l|}{ Line of business: } \\
\hline Profit & -- & ROA + & -- \\
\hline \multicolumn{4}{|c|}{ Balance sheet management: } \\
\hline $\begin{array}{l}\text { Liquidity: issuance } \\
\text { to meet existing need }\end{array}$ & $\mathrm{ROA}-, \mathrm{L} / \mathrm{D}+$ & $\begin{array}{l}\mathrm{ROA}+ \\
\mathrm{L} / \mathrm{D}-\text { and unadj, L/D + }\end{array}$ & Loan growth + \\
\hline $\begin{array}{l}\text { Liquidity: ability to } \\
\text { issue }\end{array}$ & & $\mathrm{L} / \mathrm{D}+$ & \\
\hline $\begin{array}{l}\text { Capital for } \\
\text { regulatory reasons }\end{array}$ & $\begin{array}{l}\mathrm{K} / \mathrm{A}-\text { and low relative to } \\
\text { regulatory standards }\end{array}$ & -- & $\begin{array}{l}\mathrm{K} / \mathrm{A}+\text { given it was low relative to } \\
\text { regulatory standards before }\end{array}$ \\
\hline Risk management & $\begin{array}{l}\text { Paired before and after:* } \\
\text { K/A -, L/D +, Prov/L+ }\end{array}$ & -- & $\begin{array}{l}\text { Paired before and after: } \\
\text { K/A +, L/D -, Prov/L- }\end{array}$ \\
\hline \multicolumn{4}{|l|}{ Agency reasons: } \\
\hline Empire building & -- & -- & Both TA + and ROA not + \\
\hline \multicolumn{4}{|c|}{$\begin{array}{l}\text { If the } C B \text { market requires (both of these are measures of safety for the } C B s \text { ): } \\
\begin{array}{l|l}\text { Low risk } & \text { K/A + Prov/L- }\end{array}\end{array}$} \\
\hline $\begin{array}{l}\text { Low risk } \\
\text { Paired }\end{array}$ & K/A +, Prov/L- & -- & Not K/A -, not Prov/L+ \\
\hline
\end{tabular}

* - Paired means both K/A changes, both L/D changes, and/or both Prov/L changes.

$\mathrm{TA}=$ total assets.

$\mathrm{L} / \mathrm{D}=$ loan-to-deposits ratio (adjusted to net out $\mathrm{CB}$ issue).

Unadj. $\mathrm{L} / \mathrm{D}=$ loan-to-deposits ratio (not adjusted to net out $\mathrm{CB}$ issue).

$\mathrm{K} / \mathrm{A}=$ capital-to-asset ratio.

Prov/L = provisions-to-loans ratio. 
Table IV. Determinants of the use of securitization (logit selection equation) for banks in Spain and the U.K.

Logistic regression on 496 observations of banks in Spain and the U.K over 2003-2007. The dependent variable is an indicator variable for whether a bank issues a CB, a MBS, or neither in year t. Control variables are as of the end of year t-1 (except for ROA which is for the full year). Country dummies are also included as explanatory variables. m.e. stands for marginal effect, which is the impact of marginally increasing the given variable on the probability of issuing a CB or MBS for a bank with the mean values of all the other variables. The p-values in the final column are for the test that the coefficient for the choice between CB and not issuing SMS equals the coefficient for the choice between MBS and not issuing SMS. Standard errors are clustered at the country level

\begin{tabular}{|c|c|c|c|c|c|c|c|}
\hline & \multicolumn{3}{|l|}{ CB } & \multicolumn{3}{|l|}{ MBS } & \multirow{2}{*}{\begin{tabular}{|l} 
Comparison of CB to MBS \\
$\underline{p \text {-value }}$
\end{tabular}} \\
\hline & Coeff. & $\underline{m . e}(\%)$. & $\underline{p-v a l u e}$ & Coeff. & $\underline{m . e}(\%)$. & $\underline{p \text {-value }}$ & \\
\hline$R O A$ & $-3.028 * *$ & 5.22 & 0.005 & -0.457 & -0.64 & 0.122 & 0.001 \\
\hline Adjusted loans-to-deposits ratio & $1.390^{* *}$ & 2.64 & 0.012 & $4.881 * *$ & 7.61 & 0.020 & 0.001 \\
\hline Capital ratio & $1.301 * *$ & 2.31 & 0.022 & 0.152 & 0.78 & 0.215 & 0.001 \\
\hline Low capital ratio dummy & 0.138 & 0.27 & 0.361 & 0.411 & 0.54 & 0.463 & 0.003 \\
\hline Provision-to-loans ratio & $-0.752 * *$ & -0.94 & 0.039 & $0.222 *$ & 0.33 & 0.059 & 0.001 \\
\hline Loan growth & -2.216 & -3.43 & 0.221 & 0.691 & 0.79 & 0.507 & 0.030 \\
\hline Total assets (log) & $2.004^{*}$ & 3.34 & 0.058 & $1.360 * * *$ & 2.24 & 0.021 & 0.005 \\
\hline Rating at issuance & $0.189 * *$ & 0.58 & 0.019 & $0.232 * *$ & 0.30 & 0.026 & 0.014 \\
\hline Years to maturity & $0.102 *$ & 0.17 & 0.062 & $0.167 * *$ & 0.26 & 0.018 & 0.020 \\
\hline
\end{tabular}

Base category: Non-issuer

Number of observations 496

Number of banks 140

Legend: * $\mathrm{p}<.1 ; * * \mathrm{p}<.05 ; * * * \mathrm{p}<.01$ 
Table V. Effects of the use of CB and MBS (second-stage regressions)

Regressions on the effects of SMS issue in Spain and the U.K (joint regression). Dependent variables are given in the column header and are for year $\mathrm{t}$ (year-end values except for ROA). The dummies for SMS issue take the value 1 if and only if a bank issues that type of SMS at least once in years $\mathrm{t}-1$ or $\mathrm{t}$. All the regressions have bank fixed effects, country dummies, and controls for balance sheet and income statement variables and a dummy for whether the issue was the first of its type by the bank (coefficients not reported). Standard errors are clustered at the country level.

\begin{tabular}{|c|c|c|c|c|c|c|c|c|c|c|c|c|c|c|c|c|c|c|c|c|c|}
\hline & \multicolumn{3}{|l|}{ ROA } & \multicolumn{3}{|c|}{$\begin{array}{l}\text { Adjusted loans-to- } \\
\text { deposits }\end{array}$} & \multicolumn{3}{|c|}{ Loan growth } & \multicolumn{3}{|c|}{ Capital ratio } & \multicolumn{3}{|c|}{$\begin{array}{l}\text { Capital ratio } \\
\begin{array}{l}\text { (regression } \\
\text { banks only) }\end{array}\end{array}$} & \multicolumn{3}{|c|}{ Provisions to loans } & \multicolumn{3}{|c|}{$\begin{array}{l}\text { Total assets } \\
(\log )\end{array}$} \\
\hline UK and Spain & Coeff. & \multicolumn{2}{|c|}{ p-value } & Coeff. & \multicolumn{2}{|c|}{ p-value } & Coeff. & \multicolumn{2}{|c|}{ p-value } & Coeff. & \multicolumn{2}{|c|}{ p-value } & Coeff. & \multicolumn{2}{|c|}{ p-value } & Coeff. & \multicolumn{2}{|c|}{ p-value } & $\underline{\text { Coeff }}$ & \multicolumn{2}{|c|}{ p-value } \\
\hline $\begin{array}{l}\text { Have you issued } C B \text { in the } \\
\text { last } 2 \text { years? }\end{array}$ & 0.085 & $* *$ & 0.028 & -0.041 & * & 0.075 & 0.082 & & 0.428 & 0.070 & $* * *$ & 0.007 & 0.016 & $* *$ & 0.023 & 0.063 & & 0.301 & 0.013 & $* *$ & 0.022 \\
\hline $\begin{array}{l}\text { Have you issued MBS in the } \\
\text { last } 2 \text { years? }\end{array}$ & 0.005 & & 0.271 & 0.017 & * & 0.048 & -0.045 & $* * *$ & 0.005 & 0.014 & & 0.362 & 0.017 & & 0.241 & -0.013 & $* *$ & 0.020 & 0.072 & $* * *$ & 0.006 \\
\hline $\begin{array}{l}\text { Have you issued } C B \text { in the } \\
\text { last } 2 \text { years? (first-time } \\
\text { issuers) }\end{array}$ & -0.065 & $*$ & 0.084 & -0.029 & $*$ & 0.050 & 0.056 & & 0.375 & 0.056 & $* * *$ & 0.006 & 0.014 & $*$ & 0.056 & 0.035 & & 0.262 & 0.006 & $* *$ & 0.027 \\
\hline $\begin{array}{l}\text { Have you issued MBS in the } \\
\text { last } 2 \text { years? (first-time } \\
\text { issuers) }\end{array}$ & -0.002 & & 0.227 & 0.006 & * & 0.064 & -0.025 & $* *$ & 0.012 & 0.013 & & 0.297 & 0.012 & & 0.335 & -0.011 & $* *$ & 0.039 & 0.062 & $* *$ & 0.012 \\
\hline
\end{tabular}


Table VI. Effect of market restrictions on SMS issue in Germany and the U.S.

The table presents the results for simulations under which German and U.S. banks are assumed to issue CB and MBS under the same conditions are Spanish and U.K. banks do. A bank that issues a CB in Germany is assumed to switch to a MBS if the predicted probability of issuing a CB is lower than the predicted probability of issuing a MBS using the coefficients from the results reported in Table V. A similar exercise establishes the banks in the U.S. that would switch from a MBS to a CB. For German banks that do not issue CB, the probability that they would issue MBS is calculated using the coefficients from the results reported in Table V. These probabilities are summed across all German banks that did not issue CB in a given year to get the percent of banks that switch from not issuing a SMS to issuing MBS.

Again, a similar exercise is done to derive the percentage of U.S. banks that switch from not issuing a SMS to issuing CB.

\begin{tabular}{|l|l|l|l|l|}
\hline & Switch from & Switch to & $\begin{array}{l}\text { Pct. of banks } \\
\text { that switch }\end{array}$ & $\begin{array}{l}\text { Number of } \\
\text { switches (obs.) }\end{array}$ \\
\hline \multirow{2}{*}{ Germany } & CB & MBS & $20.4 \%$ & 20 out of 96 \\
\cline { 2 - 5 } & 0 & MBS & $11.2 \% *$ & 35 out of 306 \\
\hline \multirow{2}{*}{ U.S. } & MBS & CB & $25.3 \%$ & 23 out of 91 \\
\cline { 2 - 5 } & 0 & CB & $9.4 \% * *$ & 78 out of 861 \\
\hline
\end{tabular}

Table VII. Interpretation of regression results

\begin{tabular}{|l|l|l|l|l|l|l|}
\hline & CB & \multicolumn{3}{l|}{ MBS } & \multicolumn{2}{l|}{} \\
\hline & Before & After & Consistent with & Before & After & Consistent with \\
\hline ROA & - & + & $\begin{array}{l}\text { Profit, } \\
\text { Liquidity (1) }\end{array}$ & $(-)$ & $(+)$ & \\
\hline Adjusted loans-to-deposits ratio & + & - & $\begin{array}{l}\text { Liquidity (1), } \\
\text { Risk management }\end{array}$ & + & + & Liquidity (2) \\
\hline Capital ratio & + & + & Low risk & $(+)$ & $(+)$ & \\
\hline Low capital ratio & $(+)$ & & & $(+)$ & & \\
\hline Provisions & $(+)$ & $(+)$ & & + & - & Risk management \\
\hline Loan growth & - & $(+)$ & & $(+)$ & - & Risk management \\
\hline
\end{tabular}

Liquidity (1) is issuance to meet an existing liquidity need. Liquidity (2) is the ability to issue leading to less need for balance sheet liquidity. Parentheses indicate coefficients that are not significantly different from zero. 